\title{
Growth of Douglas-fir, lodgepole pine, and ponderosa pine seedlings underplanted in a partially-cut, dry Douglas-fir stand in south-central British Columbia
}

\author{
by Alan Vyse ${ }^{1}$, Christine Ferguson², Suzanne W. Simard ${ }^{3}$, Tamaki Kano ${ }^{3}$ and Pasi Puttonen ${ }^{4}$
}

\begin{abstract}
The effects of partial cutting on seedling growth of three conifer species were studied at a very dry, hot interior Douglasfir site near Kamloops, British Columbia. Douglas-fir (Pseudotsuga menziesii var. glauca (Beissn.) Franco), lodgepole pine (Pinus contorta Dougl. ex Loud. var. latifolia Engelm.), and ponderosa pine (Pinus ponderosa Dougl. ex. P. \& C. Laws.) seedlings were planted in mechanically prepared $50 \mathrm{~cm} \times 50 \mathrm{~cm}$ patches under different canopy conditions created by harvesting $60 \%$ of the original stand volume. The prepared areas were selected to represent canopy closures from open to closed, slopes from 0 to $60 \%$, and all aspects. After six years, survival of Douglas-fir, lodgepole pine and ponderosa pine was $78 \%, 76 \%$ and $70 \%$, respectively. Light level had a strong influence on survival and condition. Growth of all species increased linearly with light, and was greatest for lodgepole pine, followed by ponderosa pine and Douglas-fir. Multiple regression analysis showed that six-year seedling size was most significantly affected by total light, and only occasionally by aspect, slope, or crown closure. The best models explained $53 \%, 47 \%$ and $42 \%$ of the variation in diameter of lodgepole pine, ponderosa pine, and Douglas-fir, respectively. Natural abundance ${ }^{13} \mathrm{C}$ was positively correlated with light and soil moisture availability, reflecting higher photosynthetic capacity of all species in the wetter, open canopy conditions. Patterns in isotopic discrimination also indicated greater water use efficiency of Douglas-fir and ponderosa pine than lodgepole pine under low light conditions. Underplanting stands thinned to a basal area of less than $15 \mathrm{~m}^{2}$ per ha offers a solution to regeneration difficulties on hot, dry Interior Douglas-fir sites.
\end{abstract}

Key words: partial cutting, Douglas-fir, lodgepole pine, ponderosa pine, light, soil moisture, ${ }^{13} \mathrm{C}$, growth, survival, Opax Mountain Silvicultural Systems Project

\section{RÉSUMÉ}

Les effets d'une coupe partielle sur la croissance des semis de trois espèces de coniferes ont été étudiés sur une station de sapin Douglas très sèche et chaude de l'Intérieur près de Kamloops en Colombie-Britannique. Des semis de sapin Douglas (Pseudotsuga menziesii var. glauca (Beissn.) Franco), de pin lodgepole (Pinus contorta Dougl. ex Loud. var. latifolia Engelm.)et de pin ponderosa (Pinus ponderosa Dougl. ex. P. \& C. Laws.) ont été plantés dans des parcelles préparées mécaniquement de $50 \mathrm{~cm} \times 50 \mathrm{~cm}$ sous différentes conditions de couvert forestier créées par la récolte de $60 \%$ du volume initial du peuplement. Les parcelles préparées ont été choisies dans le but de représenter le niveau de fermeture du couvert forestier allant d'ouvert à fermé, sur des pentes de 0 à $60 \%$ selon tous ces aspects. Après six ans, la survie des semis de sapin Douglas, de pin lodgepole et de pin ponderosa était respectivement de $78 \%, 76 \%$ et de $70 \%$. Le niveau de luminosité a eu une influence déterminante sur la survie et l'état des semis. La croissance de toutes les espèces a augmenté linéairement en fonction de la luminosité et a été la plus forte pour le pin lodgepole, suivie du pin ponderosa et du spin Douglas. L'analyse de régression multiple a indiqué que la taille des semis de six ans était le plus affectée par la luminosité totale et seulement à l'occasion par l'aspect, la pente ou la fermeture du couvert. Les meilleurs modèles ont expliqué $53 \%, 47 \%$ et $42 \%$ de la variation du diamètre respectivement pour le pin lodgepole, le pin ponderosa et le sapin Douglas. L'abondance naturelle du ${ }^{13} \mathrm{C}$ a été corrélée positivement avec la luminosité et la disponibilité de l'eau dans le sol, reflétant une capacité de photosynthèse plus élevée de toutes les espèces sous des conditions de couvert plus humide et ouvert. Les patrons de différence isotopique ont indiqué également une meilleure efficacité d'utilisation de l'eau pour le sapin Douglas et le pin ponderosa que pour le pin lodgepole sous des conditions de faible luminosité. Le reboisement des peuplements éclaircis à un niveau de surface terrière de moins de $15 \mathrm{~m} 2$ par ha constitue une solution par palier aux problèmes de régénération des stations de sapin douglas chaude et sèche de l'Intérieur.

Mots clés : coupe partielle, sapin Douglas, pin lodgepole, pin ponderosa, luminosité, humidité du sol, ${ }^{13} \mathrm{C}$, croissance, survie, Opax Mountain Silvicultural Systems Project

\footnotetext{
${ }^{1}$ Emeritus Research Forester, Southern Interior Region, B.C. Forest Service, 515 Columbia Street, Kamloops, V2C 2T7. E-mail: vyse@telus.net. Corresponding author.

${ }^{2}$ Consultant, Kamloops, B.C. E-mail:ferguson@sageserve.com

${ }^{3}$ Department of Forest Sciences, University of British Columbia. 2424 Main Mall, Vancouver, B.C. V6T 1 Z4.

${ }^{4}$ Research Director, METLA, Finnish Forest Research Institute, Unionkatu 40A, FI-00710, Helsinki, Finland. E-mail: Pasi.puttonen@metla.fi
} 


\section{Introduction}

Harvesting in the hot, dry Douglas-fir forest type of southcentral British Columbia is usually carried out using standlevel partial cutting prescriptions (Vyse et al. 1991). The size, number and distribution of remaining stems depend upon the forester's prescription, and skill of the loggers. While existing seedling banks and natural regeneration are expected to lead to a well-stocked understory in the northern portion of this forest type (Armleder et al. 1986, Williams et al. 1999), regeneration has been slow at best on dry sites in more southerly areas of British Columbia, where the climate is drier and warmer (Klenner and Vyse 1998, Huggard et al. 2005). Many logged stands have been excluded from annual allowable cut calculations for this reason (Thrower and Associates 1999). Planting is an obvious solution to the problem, but in the dry climate of the Douglas-fir forests, this technique has often met with failure (Fleming et al. 1998, Newsome 1998, Heineman et al. 2003), and planted seedlings are thought to require shade to survive.

Silvicultural systems that retain substantial levels of canopy trees create unique growing conditions for planted seedlings (Coates and Burton 1999). The remaining trees form an uneven canopy, resulting in a variety of microenvironments in the understory. These microenvironments are created by the interactions of light, moisture, and nutrient availability, which can be affected by aspect, slope, soil type, surrounding ground vegetation, and size and distribution of the remaining trees. Light is considered of key importance as it directly affects photosynthesis and growth in trees, and affects other environmental conditions such as soil moisture and temperature (Emmingham and Waring 1973, Pacala et al. 1994, Lieffers et al. 1999). However, open canopies with high light in the hot, dry climate of the Interior Douglas-fir (IDF) biogeoclimatic zone (Lloyd et al. 1990) also favour growth of shrubs and grasses, which can compete with tree seedlings for soil moisture (Fleming et al. 1998, Simpson 2000, Heineman et al.2003, Simard et al. 2003, Huggard et al. 2005), leading to regeneration difficulties. Open canopies are also more subject to growing season frost conditions (Stathers 1989, Daintith et al. 1993, Fleming et al. 1998, Heineman et al. 2003, Simard et al. 2003). Conversely, more closed canopies can favour early seedling survival, but may be detrimental to long-term seedling growth because overstory trees compete intensely for soil moisture (Simpson 2000).

Because tree species vary in their tolerance to environmental conditions, the different microenvironments created through partial cutting may favour different species of seedlings, even within a single harvested area. Exploiting differences in microenvironments to improve regeneration requires knowledge of conditions that are preferred by different species. Our understanding of the relative tolerances of British Columbia's main conifer species to light, soil moisture and soil nutrient availability is based on a combination of field observations (Klinka et al. 2000) and numerous studies that have examined responses of naturally regenerated seedlings to microsite conditions (Carter and Klinka 1992, Klinka et al. 1992, Wright et al. 1998, Williams et al. 1999, Drever and Lertzman 2001). Desirable field conditions for planted seedlings have been studied under a range of conditions in wetter ecological zones (e.g., Coates and Burton 1999, Huggard and Vyse 2003, Mitchell et al. 2004, Delong et al.
2005), but only in open, clearcut environments in the dry IDF zone (Fleming et al. 1998, Newsome 1998, Heineman et al. 2003, Simard et al. 2003), with the exception of Daintith et al. (1993) who reported on Douglas-fir planted under a canopy of lodgepole pine.

In this study, we examined whether planting seedlings under a partially cut Douglas-fir canopy has the potential to increase stocking to acceptable levels. Our study was designed to determine the survival and growth responses of underplanted Douglas-fir (Pseudotsuga menziesii var. glauca (Beissn.) Franco), lodgepole pine (Pinus contorta Dougl. ex Loud. var. latifolia Engelm.), and ponderosa pine (Pinus ponderosa Dougl. ex. P. \& C. Lawson), to a range of opening sizes, aspects and slopes occurring in a partially cut hot, dry IDF forest in south-central British Columbia. We chose these three species because they dominate forest composition in the IDF zone. Douglas-fir occurs throughout the zone, while lodgepole pine is more common at higher elevations in cooler, moister climates. Ponderosa pine occurs at the lowest elevations on drier, warmer sites. All three species may occur together, although Douglas-fir is usually dominant (Hope et al. 1991). According to Klinka et al. (2000), Douglas-fir is considered shade-tolerant and ponderosa pine shade-intolerant in warm dry climates, such as on our study site. Lodgepole pine has been characterized as slightly more shade-tolerant than ponderosa pine (Ferguson et al. 1986), but has performed as well as more tolerant species under low light (Coates and Burton 1999). Both pine species are considered highly tolerant of drought and Douglas-fir moderately tolerant. An interaction between shade tolerance and soil moisture has also been found; for example, Douglas-fir is considered more shade-tolerant on dry than wet sites (Carter and Klinka 1992, Drever and Lertzman 2001).

The specific objectives of this study were to determine whether: (1) survival, growth, photosynthetic capacity or water use efficiency (using natural abundance of ${ }^{13} \mathrm{C}$; Dawson et al. 2002) vary with light availability; (2) growth responses to light vary with species as predicted by traditional shade tolerance rankings; (3) there exists a light threshold at which each species responds; and (4) responses to light vary with canopy closure, microsite aspect, and slope. Our null hypothesis was that canopy closure has no effect on seedling performance, resulting in consistent survival, growth, photosynthetic capacity and water use efficiency across all light levels. Additionally, we expected that species responses would follow traditional patterns of shade and drought tolerance.

\section{Methods \\ Study site}

This experiment was conducted at Mud Lake within the Opax Mountain Silvicultural Systems Trial (Klenner and Vyse 1998), which is located at $1000 \mathrm{~m}$ asl, approximately $20 \mathrm{~km}$ northwest of Kamloops, British Columbia (Fig. 1). The forest is dominated by Douglas-fir, with several age cohorts present on the site. Occasional stems of ponderosa pine and lodgepole pine are also present. The site is in the very dry, hot Interior Douglas-fir biogeoclimatic (IDFxh) subzone (Lloyd et al. 1990). Mean annual precipitation for this subzone is 379 $\mathrm{mm}$, with $50 \%$ falling in May to September (Lloyd et al. 1990). Snow begins to accumulate by mid-November and disappears in late April. Soil moisture deficits generally 


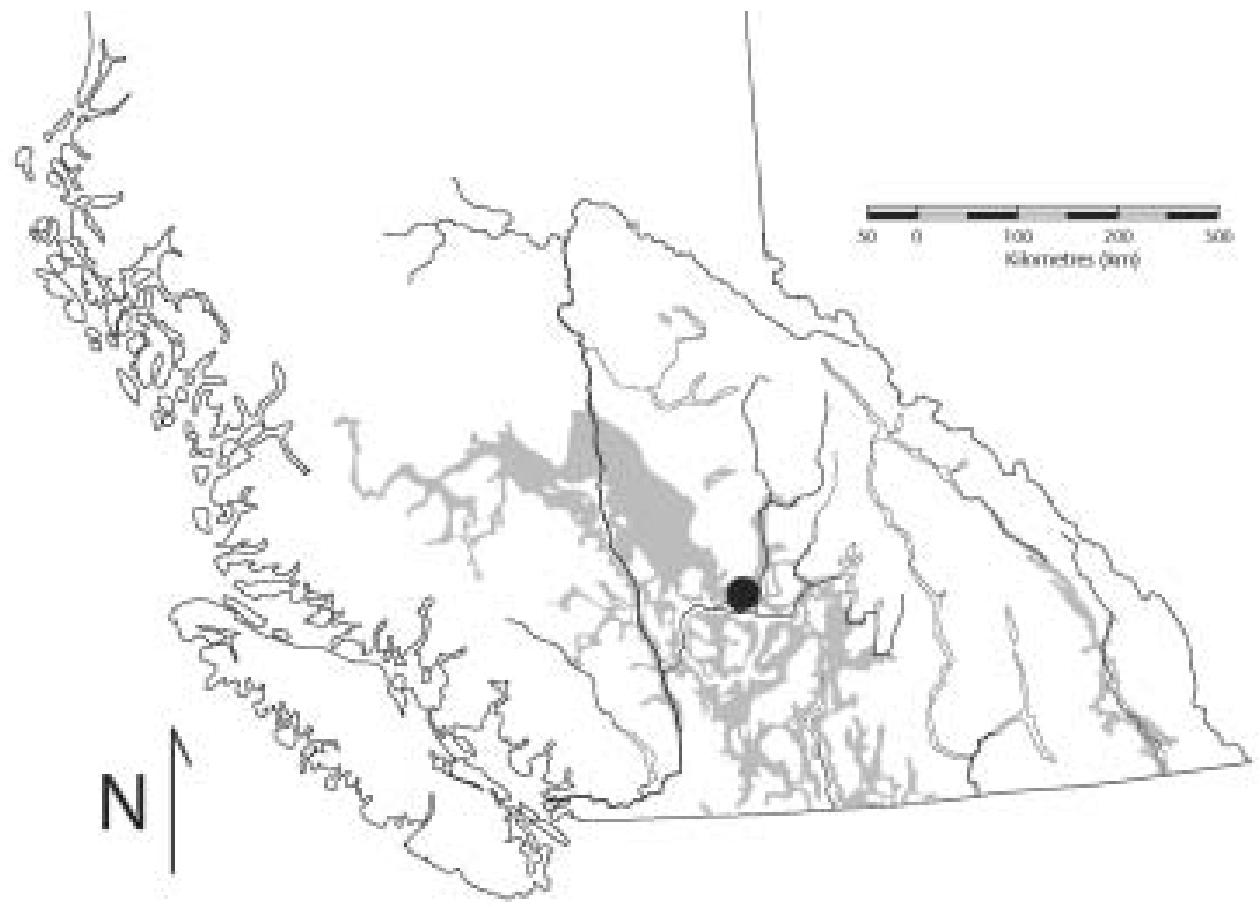

Fig. 1. Location of the Opax Mountain Research Project and the Interior Douglas-fir zone in British Columbia.

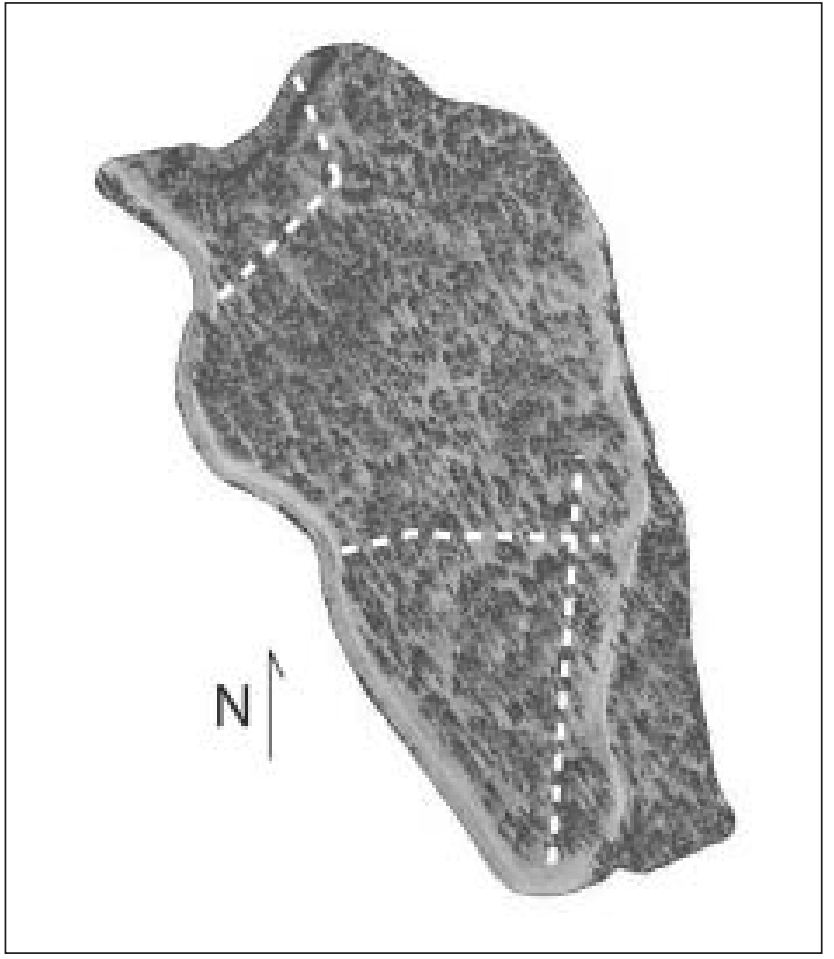

Fig. 2. Aerial view of the underplanting trial area showing the location of sampling transects.

develop by mid-August. Mean annual temperature for the subzone is $4.8^{\circ} \mathrm{C}$. Mean monthly temperatures in May to September between 1997 and 2001, in a clearing approximately $200 \mathrm{~m}$ above the study site, ranged between $9.7^{\circ} \mathrm{C}$ and $15.6^{\circ} \mathrm{C}$ (R. Adams and A. Orchansky, unpublished data). Soils are loamy Eutric Brunisols with forest floors 2.5 to $3.0 \mathrm{~cm}$ deep. The understory is dominated by pinegrass (Calamagrostis rubescens Buckl.), with lesser amounts of showy aster (Aster conspicuous LindC.), and some moss cover in low light and on north aspects. Shrub cover is low and includes snowberry (Symphoricarpos albus (L.) Blake), Saskatoon (Amelanchier alnifolia Nutt.), and birch-leaved spirea (Spirea betulifolia Pall.)

\section{Treatments and measurements}

The experiment was conducted in a 21-ha stand comprised primarily of Douglas-fir. The stand was logged in the late 1950s and older stumps are also present, presumably dating to settlement of the area between 1900 and 1910. It was again logged in the winter of 1993-94 as part of the Opax Mountain Silvicultural Systems experiment (Huggard et al. 2005). Most trees $>40 \mathrm{~cm}$ in diameter (at breast height), amounting to $140 \mathrm{~m}^{3}$, or $63 \%$ of the original standing volume (Bealle-Statland 1998), were removed. All snags were felled. Fig. 2 illustrates the open, clumpy stem distribution post-harvest, and Fig. 3 shows the diameter distribution pre- and postharvest.

In the spring of 1994, the harvested area was mechanically site prepared with a back-hoe to create small patches $(50 \mathrm{~cm}$ $\times 50 \mathrm{~cm}$ ) of exposed mineral soil, into which seedlings were planted. Site preparation was carried out to reduce competition for soil moisture from pinegrass. The threat of frost damage was considered low because of the low elevation, moderate slopes, and high amount of overstory protection.

In 1996, 900 of these patches were described in terms of canopy closure (measured with a spherical densiometer; Lemmon 1957), basal area (measured using a prism with a 


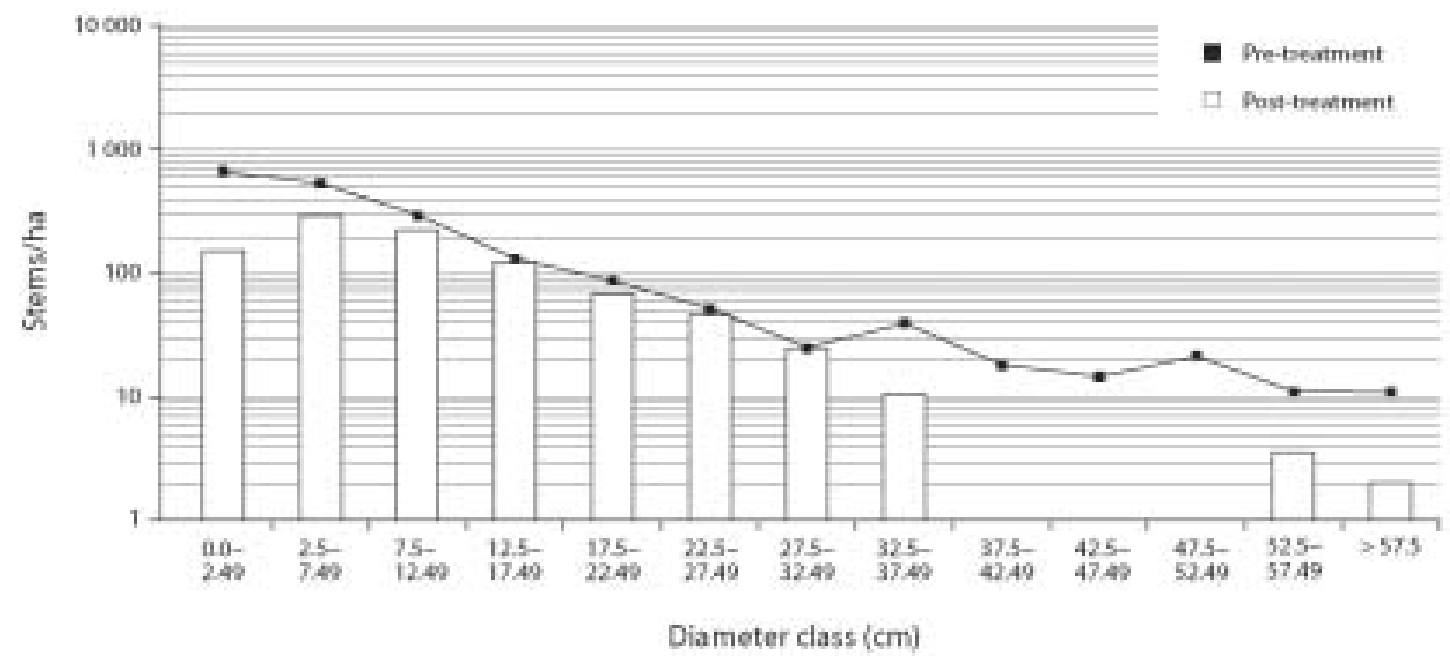

Fig. 3. Stand structure of underplanting trial area (reprinted from Bealle-Statland 1998, p 145 with permission from B.C. Ministry of Forests].

Table 1. Seedlot, stock type and dimensions of planting stock by species.

\begin{tabular}{|c|c|c|c|c|}
\hline Species & Seedlot & Stock type & $\begin{array}{l}\text { Height } \\
\text { range } \\
(\mathrm{cm})\end{array}$ & $\begin{array}{c}\text { Diameter } \\
\text { range } \\
(\mathrm{cm})\end{array}$ \\
\hline Douglas-fir & 8273 & $1-0$ PSB 415 B & $15-25$ & $2.0-4.0$ \\
\hline Lodgepole pine & 30896 & $1-0$ PCT 313 B & $7-16$ & $2.2-3.7$ \\
\hline Ponderosa pine & 41289 & $1-0$ PCT 313 B & $6-16$ & $1.9-3.9$ \\
\hline
\end{tabular}

basal area factor of one), slope, aspect, slope position, and soil coarse fragment content. The patches were then assigned to a canopy closure class $(1=0-20 \% ; 2=21-40 \% ; 3=$ $41-60 \% ; 4=61-80 \% ; 5=81-100 \%)$. One-third of the patches were randomly selected from across the canopy closure classes, ensuring full representation of the light and physical microenvironment conditions that existed on the site. In the spring of 1997, the selected patches were cleared of encroaching vegetation by hand, and planted with one seedling of each of the three species. Seedling stock types and sizes are shown in Table 1.

In 1999, light conditions were quantified for all planted patches using hemispherical photographs (Canham 1988). The photographs were taken with a Minolta X700 camera, Minolta $7.5 \mathrm{~mm}$ circular image fisheye lens, and 400 ASA colour print film. Exposures were made only during periods of overcast sky or when the sun was low in the horizon to avoid uneven exposure of photographs. The camera was levelled and faced true north at $70 \mathrm{~cm}$ height directly above each patch. The photos were digitized and then analyzed using GLI/C software (Canham 1995). Crown canopy conditions change slowly in these forest types and the values obtained three seasons after planting are considered representative of the six-year measurement period.

The seedlings were assessed for condition, size, damage cause, and mortality in the fall of 1997, 1999, 2000, and 2002.

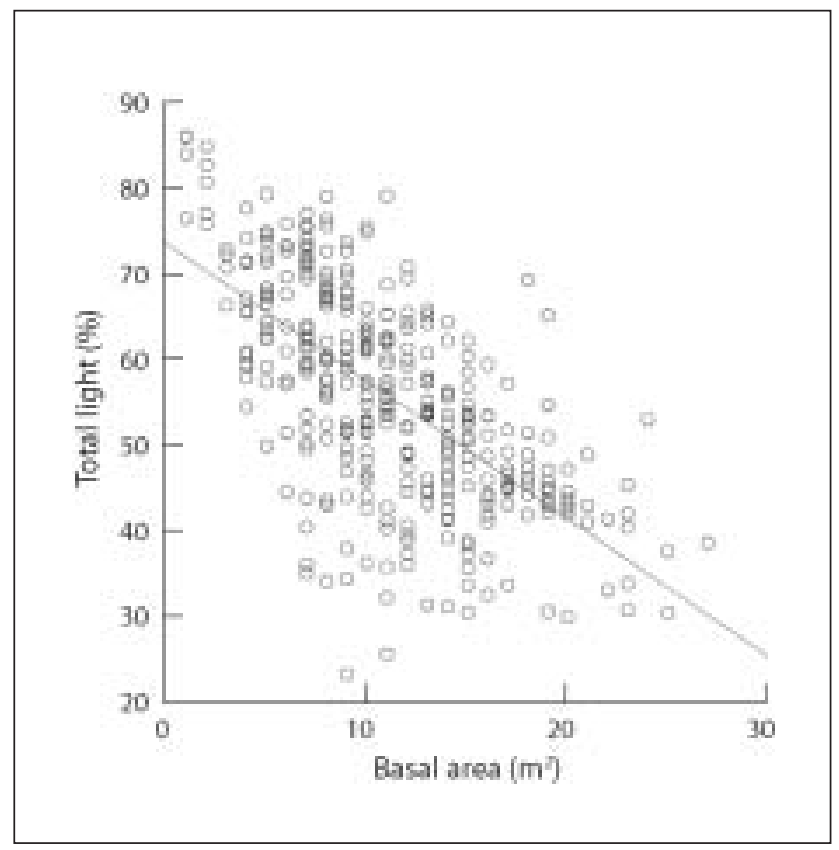

Fig. 4. Relationship between basal area and percent total light measured by hemispherical photography. (total light $\%=72.986$ - 1.607 BA; $r^{2}=0.418 ; p<0.001$ ).

Also in 2002, 35 seedlings were randomly selected from across the full light spectrum for assessment of natural abundance of ${ }^{13} \mathrm{C}$ in wood. Shoots were harvested at ground level and a $1-\mathrm{cm}$ section was cut from the base. The latest five growth rings were hand-filed from the top side to produce powder samples, which were analyzed for ${ }^{13} \mathrm{C}$ using an AS autosampler of a Thermoquest NC 2500 elemental analyzer (Carlo Erba Instruments, Milan, Italy). Lab standards were calibrated against the international calcium carbonate standards NBS 19 (1.95) and NBS 20 (-1.06). Carbon isotopic values are listed relative to Vienna Peedee Belemnite (vpdb) (Wolf et al. 1994). 


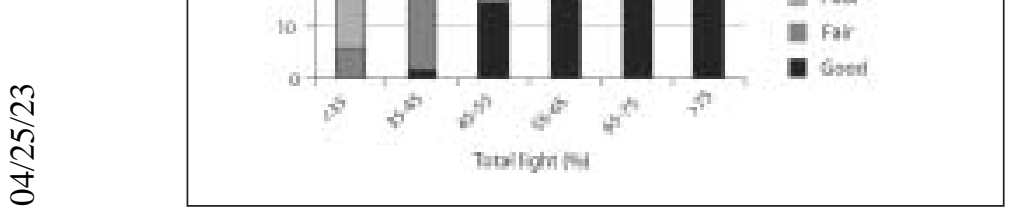

Fig. 5. Douglas-fir seedling condition by light class after six years.

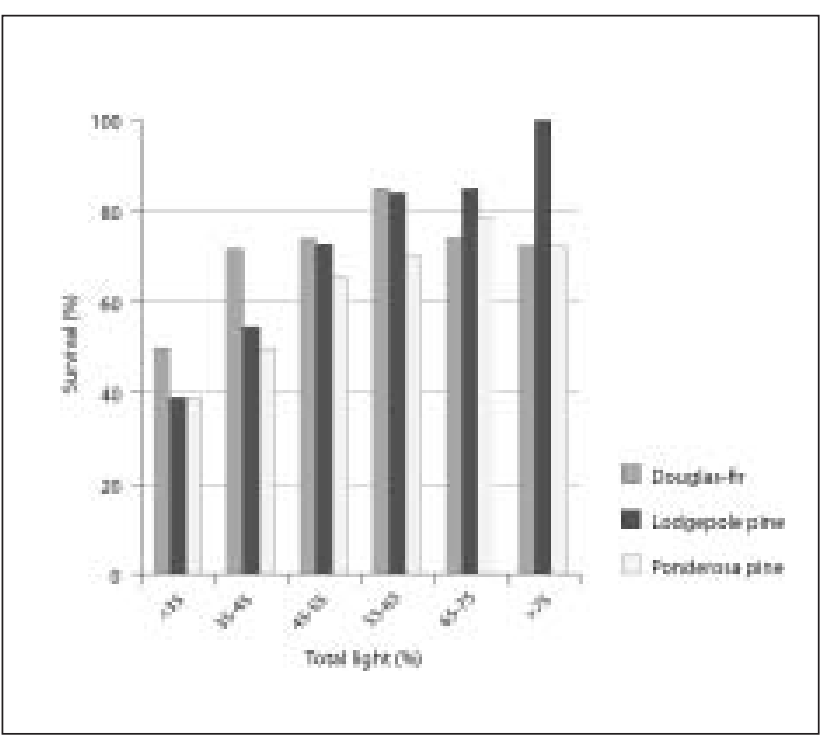

Fig. 6. Six-year survival of Douglas-fir, lodgepole pine and ponderosa pine by light class.

\section{Statistical Analysis}

All data were analyzed using SYSTAT 7.0 (SPSS 1997). Simple or multiple regression analyses were carried out to explore relationships between seedling variables (diameter, height, or ${ }^{13} \mathrm{C}$ ) and environmental characteristics of the planting patches (total light availability, canopy closure, slope, or aspect). Simple regression was also used to characterize relationships between total light availability and patch neighbourhood characteristics (canopy closure and basal area). None of the data required transformations to stabilize variances. For regressions between diameter or height and total light availability, the extra sums of squares principle was used to test whether full regression models that included separate slope and intercept terms for each species had a better fit than simple models with only one slope and one intercept (Draper

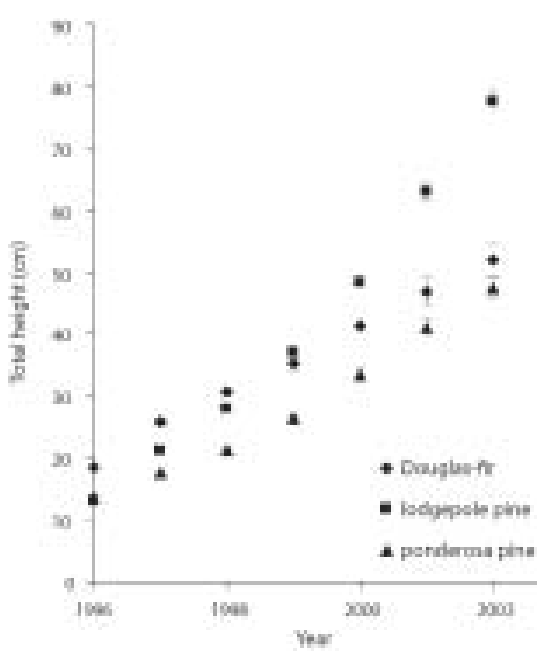

Fig. 7. Mean height growth \pm SED of seedlings over time by species.

and Smith 1998). Indicator variables were used to remove species terms from the full model and an F-test was used to test whether there were significant changes in the sums of squares. Survival data was analyzed using binary logit analysis (Tabachnick and Fidell 2001). Seedling survival, growth and condition were also summarized by $10 \%$ light and $20 \%$ canopy closure classes.

\section{Results}

\section{Light availability}

Total light availability ranged from $20 \%$ to $85 \%$ full sunlight, and included undisturbed forest, single tree removal gaps, and small patch harvests (Fig. 4). Linear regression showed that basal area of neighbours accounted for $42 \%$ of the variation in total light as measured by the gap light index. Similarly, canopy closure measured with the spherical densiometer accounted for $60 \%$ of the variation in total light (Total light $=73.482-0.369^{\star}$ Canopy Closure; $\mathrm{p}<0.001$ ).

\section{Seedling survival, condition and damage}

Overall six-year seedling survival was 78\%, 76\% and 70\% for Douglas-fir, lodgepole pine, and ponderosa pine, respectively. Survival of each species had declined steadily over the six seasons and more mortality is expected in future. About $50 \%$ of the Douglas-fir and ponderosa pine seedlings, and 64\% of lodgepole pine, were in good condition after six years. Light level had a strong influence on survival and condition (Fig. 5 and 6). Binary logit analysis showed that the relationship between survival and total light was significant for each species ( $\mathrm{p}<0.05$, data not shown). By contrast, neither slope nor aspect had a strong effect on survival (data not shown).

Causes of mortality other than shading were not evident. Although there was a region-wide drought in the summer of 1998 (Environment Canada 2005), mortality at our site did not markedly increase in response. Small mammals (snowshoe hares and voles) caused a minor amount of damage. Cattle damage and frost have caused substantial mortality elsewhere in the dry Douglas-fir type (Newsome 1998), but 
a)

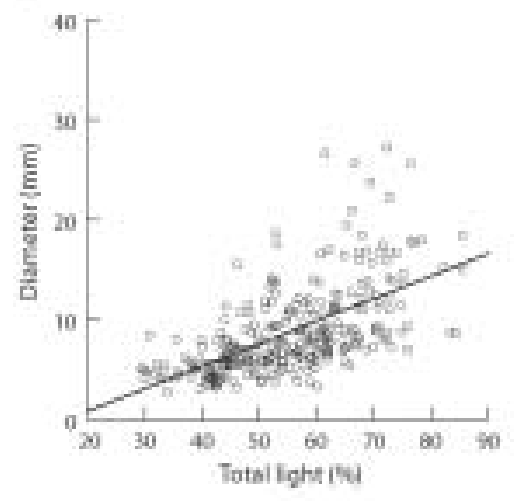

a)

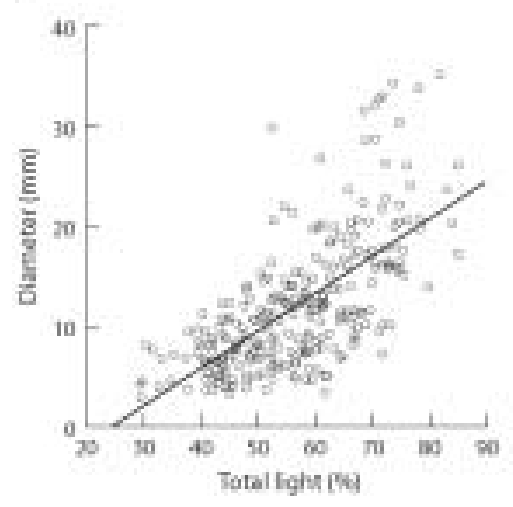

b)

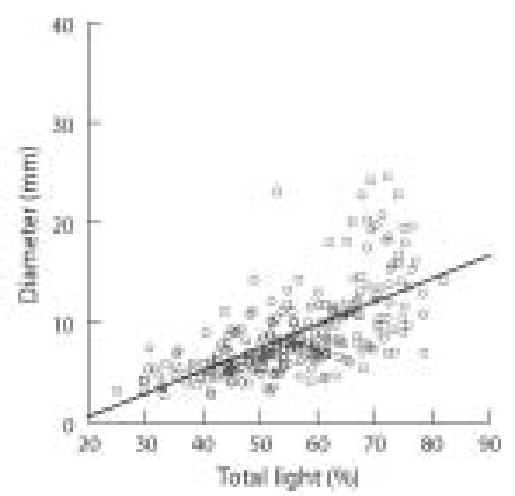

Fig. 8. Relationship between 2002 diameter (y) and total light $(x)$ of under-planted (a) Douglas-fir $\left(y=-9.90+0.28 x ; R^{2}=0.32 ; P\right.$ $<0.001 ; n=272$ seedlings), (b) ponderosa pine (y = -7.46 + 0.27x; $R^{2}=0.29 ; P<0.001 ; n=233$ seedlings), and (c) lodgepole pine $\left(y=-19.35+0.61 x ; R^{2}=0.38 ; P<0.001 ; n=261\right.$ seedlings $)$.

cattle were excluded from our study site and frost was not important due to slope and canopy conditions.

\section{Seedling growth}

Annual height growth varied considerably, but all species followed a similar pattern over time (Fig. 7), with a reduction the year after planting (1998, a drought year), followed by slow recovery in subsequent years. Lodgepole pine seedlings grew the tallest, followed by Douglas fir, then ponderosa pine. Diameter growth followed the same pattern as height growth (data not shown).

Simple linear regression analysis, which provided the best fit, showed that six-year diameter and height growth in 2002 were strongly influenced by total light for all three species (Fig. 8 and 9). Total light accounted for $53 \%, 47 \%$ and $42 \%$ of the variation in diameter of lodgepole pine, ponderosa pine and Douglas-fir, respectively. Models for height were less predictive, with light accounting for only $42 \%, 30 \%$ and $35 \%$ of the variation in height growth of these three species, respectively. The extra sums of squares analysis showed a significant effect of species for both diameter and height. Removing either separate intercept or slope terms from the full model significantly reduced the sums of squares $(\mathrm{P}<0.001)$, indicating species identity affected the relationship between light and growth. Lodgepole pine response to light differed from ponderosa pine and Douglas-fir, with steeper slopes for both diameter and height growth in the last year of measurement (Fig. 8 and 9). The strong effect of light on seedling growth was also evident in the relationship between seedling height and canopy closure class (data not shown).

Multiple regression analysis confirmed our result that, of all the environmental variables considered, total light availability most strongly affected seedling diameter (Table 2). Slope, aspect, height at the time of planting, canopy closure, and basal area of neighbouring overstory stems were of minor importance in the models, even though they were occasionally significant. In spite of these regression results, graphical summaries showed that height growth of all species tended to be greatest on easterly aspects and lowest on southerly aspects.

\section{Natural abundance 13C analysis}

All three species had significant relationships between logtransformed total transmitted light and $\delta^{13} \mathrm{C}$ values $(\mathrm{p}<0.001$, Fig. 10). Of the three species, lodgepole pine had the strongest and steepest relationship between total light and $\delta^{13} \mathrm{C}$ values. 

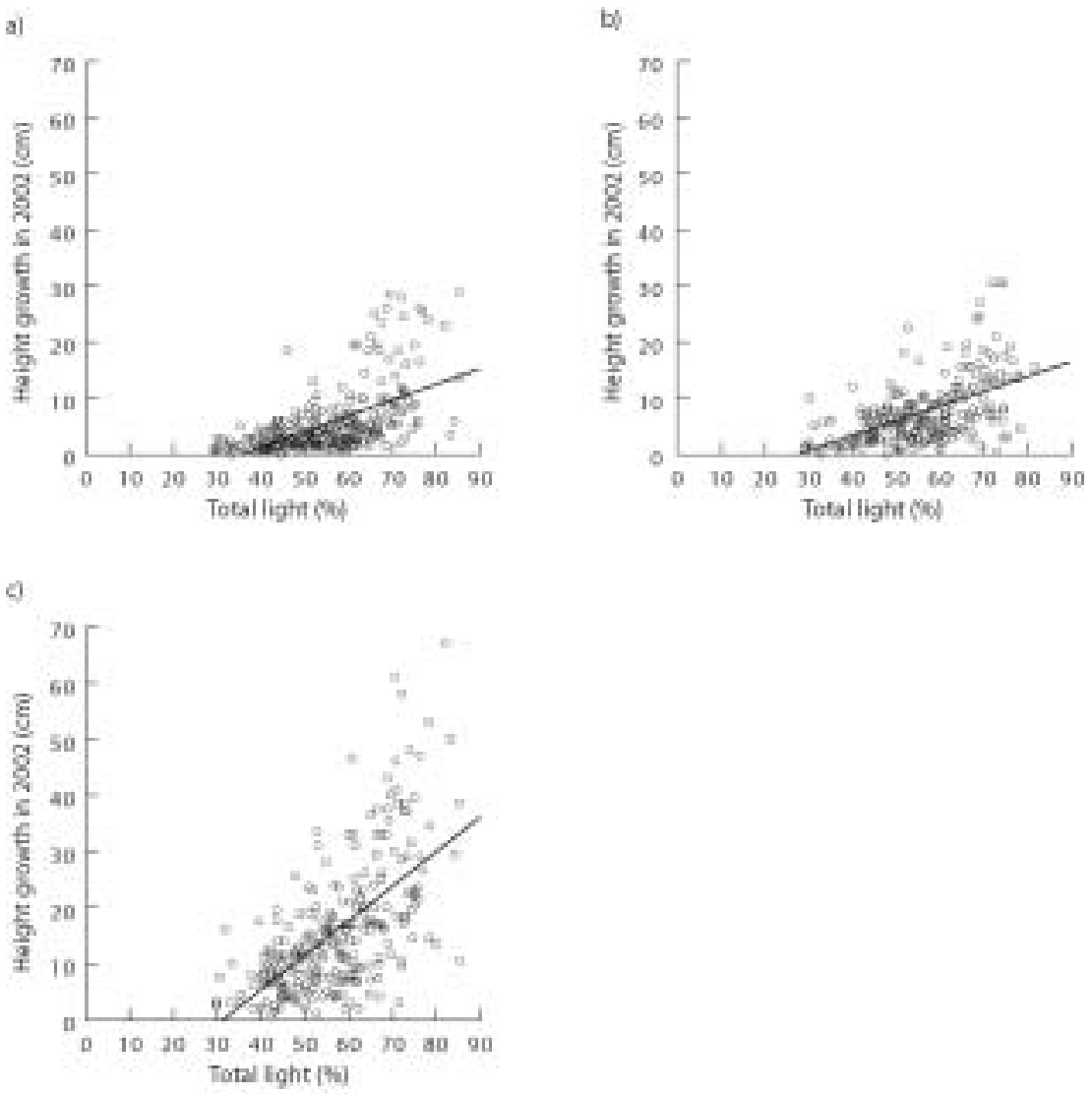

Fig. 9. Relationship between 2002 height growth (y) and total light $(x)$ of under-planted (a) Douglas-fir ( $y=-3.26+0.23 x ; R^{2}=$ $0.36 ; P<0.001 ; n=276$ seedlings), (b) ponderosa pine (y = -3.99+0.23x; $R^{2}=0.40 ; P<0.001 ; n=246$ seedlings), and (c) lodgepole pine ( $y=-9.34+0.37 x ; R^{2}=0.44 ; P<0.001 ; n=266$ seedlings)

Table 2. Coefficient of determination and partial $\mathbf{R}^{2}$ values for multiple regression models relating diameter with microsite environment and stand variables for each underplanted species

\begin{tabular}{|c|c|c|c|c|c|c|c|}
\hline Species & $\mathrm{R}^{2}$ & Total light & Aspect & $\begin{array}{l}\text { Crown } \\
\text { cover }\end{array}$ & $\begin{array}{l}\text { Height } \\
\text { when } \\
\text { planted }\end{array}$ & $\begin{array}{l}\text { Neighbour } \\
\text { basal area }\end{array}$ & Slope \\
\hline Douglas-fir & 0.400 & 0.339 & 0.020 & 0.026 & 0.008 & 0.006 & $<0.001$ \\
\hline Lodgepole pine & 0.499 & 0.447 & 0.013 & 0.005 & 0.033 & $<0.001$ & 0.002 \\
\hline Ponderosa pine & 0.428 & 0.318 & 0.084 & $<0.001$ & 0.023 & 0.003 & $<0.001$ \\
\hline
\end{tabular}

For all three species, $\delta^{13} \mathrm{C}$ was more strongly related to increasing light than to decreasing basal area of the neighbouring canopy trees (data not shown). The average $\times{ }^{13} \mathrm{C}$ isotope signature across all light levels was similar among species, averaging $-27.8 \pm 0.08 \%$, $-27.6 \pm 0.08 \%$, and -27.5 $\pm 0.09 \%$ o for lodgepole pine, Douglas-fir and ponderosa pine, respectively $(\mathrm{p}>0.05)$. However, isotopic discrimination increased with decreasing light availability, and was affected by species identity at low light levels. ${ }^{13} \mathrm{C}$ was more depleted for lodgepole pine $(-28.4 \pm 0.19 \%$ ) than Douglas-fir $(-27.9 \pm 0.18 \%$ o $)$ or ponderosa pine $(-27.7 \pm 0.18 \%$ ) below $50 \%$ light $(\mathrm{p}<0.001)$, but did not differ among species
$(-27.5 \pm 0.08 \%$ o, $-27.55 \pm 0.08 \%$, and $-27.45 \pm 0.10 \%$, respectively) above $50 \%$ light ( $\mathrm{p}>0.05)$.

\section{Discussion}

As expected, we found that light levels were related to basal area across the range of conditions on our site $\left(0-30 \mathrm{~m}^{2}\right.$, see Fig. 4). Comeau et al. (1998) and Delong et al. (2005) found similar results on moister sites in the Sub-boreal Spruce and Interior Cedar-Hemlock biogeoclimatic zones, respectively.

Six-year seedling survival was high compared with other planting studies in the dry, hot IDF forests of interior British Columbia, where Douglas-fir survival has commonly been 
at

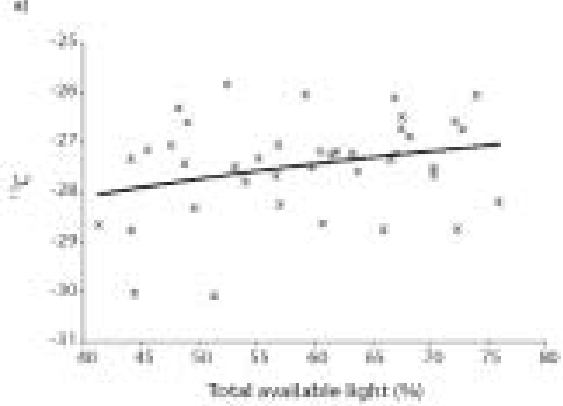

b)

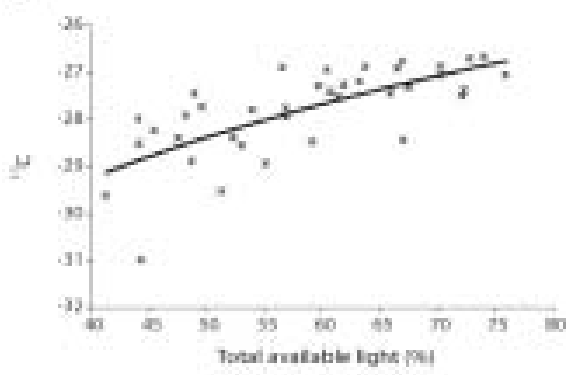

a

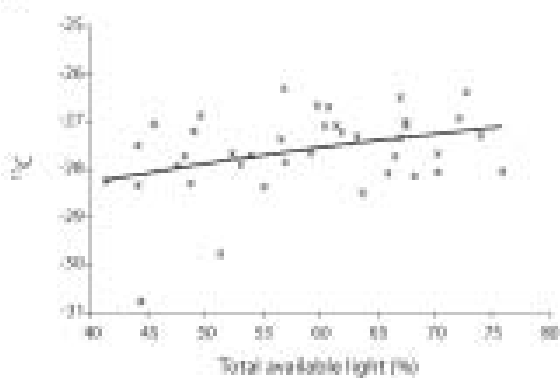

Fig. 10. Relationship between wood $\delta^{13} \mathrm{C}(\mathrm{y})$ and log-transformed total transmitted light $(\mathrm{x})$ for (a) Douglas-fir $(\mathrm{y}=1.86 \mathrm{Ln}(\mathrm{x})$ $-35.21 ; R^{2}=0.134 ; P<0.001$ ), (b) lodgepole pine $\left(y=3.88 \operatorname{Ln}(x)-43.56 ; R^{2}=0.509 ; P<0.001\right)$, and (c) ponderosa pine $\left(y=1.64 \operatorname{Ln}(x)-34.13 ; R^{2}=0.078 ; P<0.001\right)$.

less than 50\% (Fleming et al. 1998, Newsome 1998, Simard et al. 2003). We found that survival tended to increase with light availability, exceeding $80 \%$ for lodgepole pine and $70 \%$ for Douglas-fir and ponderosa pine when total light rose above $55 \%$. There was a light threshold at $45 \%$ for lodgepole pine and ponderosa pine where survival dropped below $60 \%$ for both species. Survival for Douglas-fir did not drop below $60 \%$ until light was less than $35 \%$. This provides some support for existing shade tolerance information for British Columbia, which states that lodgepole pine and ponderosa pine are not as well adapted to shade as Douglas-fir (Williams et al. 1999, Klinka et al. 2000). However, our results also agree with Coates and Burton (1999), who found that lodgepole pine survived and grew well not only in open conditions, but also in lower light conditions compared with supposedly more shade-tolerant species. We expect more mortality to occur over the next several years; however, some seedlings will

likely survive, even in portions of the stand with low light conditions.

That all species survived well in the most open conditions, where we also observed the greatest understory grass, herb and shrub abundance, suggests that preparing small, vegetation-free planting spots is sufficient to achieve adequate understory stocking. In adjacent large openings ( $>0.1$ ha in size with all trees removed) on the same site, Huggard et al. (2005) similarly found that small patch site preparation was adequate for good survival. On another dry, cool IDF site that had been clearcut, Simard et al. (2003) also found that lodgepole pine survival reached $80 \%$ in small $(90 \mathrm{~cm} \times 90 \mathrm{~cm})$ grass-free prepared patches, but that it reached $97 \%$ in larger $(90 \mathrm{~cm} \times 180 \mathrm{~cm})$ patches. Larger patches may be necessary to improve survival on clearcut sites where frost susceptibility (Fleming et al. 1998) and pinegrass competition tend to be greater (Heineman et al. 2003).

As with survival, the best seedling growth occurred in the most open canopy conditions. We found there was no canopy closure threshold for growth response of any species. Our seedlings may not have reached their maximum growth potential (Wright et al. 1998), however, because our largest gaps were only 0.1 ha in size, and fewer than $2 \%$ of the patches had $>80 \%$ available light. Even so, seedlings planted in nearby $>0.1$-ha patch cuts grew only marginally better (Huggard et al. 2005), suggesting that canopy thresholds for growth do not exist on this site. Lodgepole pine seedling growth responded more strongly to light than either ponderosa pine or Douglas fir, except at the lowest light levels, where its growth was similar to the other species.

The positive correlation between $\delta^{13} \mathrm{C}$ values and light availability with increasing crown openness for all species in our study may have indicated either (a) increased photosynthetic capacity because of increased mesophyll $\mathrm{CO}_{2}$ conductance (reduced fractionation by Rubisco; Virgona and Farquhar 1996) or (b) increased water use efficiency because of greater stomatal closure under soil moisture stress (Dawson et al. 2002). On our site, however, soil moisture was found to increase with crown openness in June (G.D. Hope, personal communication), likely because tree removal reduced the transpirational demand in the resulting forest gaps. This suggests that increasing $\delta^{13} \mathrm{C}$ values reflected enhanced photosynthetic efficiency rather than increased water use efficiency. Conifers have been shown in other studies to have less negative $\delta^{13} \mathrm{C}$ values in response to irrigation or fertilization, which has been attributed to higher photosynthetic capacity rather than lower stomatal conductance (Livingston et al. 1999). The weaker relationship between $\delta^{13} \mathrm{C}$ and basal area of neighbouring trees than between $\delta^{13} \mathrm{C}$ and light availability suggests that the enhanced photosynthetic capacity was related more to light than soil resource (water and nutrient) increases following tree removal. In nearby larger openings on our site, Paterson (1997) found that by August, soil moisture levels in clearcut openings converged with those in neighbouring forests, probably because of the high abundance of rapidly transpiring pinegrass in the openings (Nicholson 1989). Pinegrass has a remarkable ability to exhaust soil moisture reserves (Fleming et al. 1994), and together with trees, contributes to soil moisture depletion regardless of canopy opening size. Nevertheless, our wood $\delta^{13} \mathrm{C}$ values suggest that any late season reductions in soil 
moisture in the larger openings had a minor effect on seedling performance since the growth rings integrate conditions over the whole growing season.

The pattern of isotopic discrimination across light levels by lodgepole pine differed from Douglas-fir and ponderosa pine, particularly at levels below light saturation (Lavender 1990). We found lower $\delta^{13} \mathrm{C}$ values for lodgepole pine than Douglas-fir and ponderosa pine at light levels under 50\%, suggesting lower water use efficiency for lodgepole pine under shaded conditions. Similar patterns in $\delta^{13} \mathrm{C}$ discrimination among species differing in shade tolerance have been observed by others (Marshall and Zhang 1994, Brooks et al. 1997). This indicates that Douglas-fir and ponderosa pine close their stomates more readily than lodgepole pine under shade to conserve water, resulting in lower discrimination against ${ }^{13} \mathrm{C}$ during carboxylation.

Increasing seedling performance with canopy openness in our study suggests that future cuts should favour aggregated retention for planted regeneration rather than dispersed retention, which currently is the favoured cutting method for the dry Douglas-fir forest type (Ministry of Forests 1992). Large trees strongly influence small trees (Goldberg et al. 1999, Grime 2001) by competing for light and soil moisture (Simpson 2000), and if they are retained throughout the stand, small trees will remain in a suppressed condition for many years. Creating small openings in mature Douglas-fir forests, moreover, has been shown to improve mule deer winter range habitat (Armleder et al. 1986).

One of the challenges of applying partial cutting prescriptions to achieve appropriate light conditions is marking the trees to cut. We found that basal area could be used as a rough indicator of light conditions in the stand we studied (see Fig. 4). Thus, a marking guide for thinning and harvesting prescriptions in this, and similar, stands might specify that stand basal area be reduced below $15 \mathrm{~m}^{2}$ to achieve survival rates above $60 \%$, and below $10 \mathrm{~m}^{2}$ to achieve good growth.

Underplanting in the hot, dry IDF subzone following partial cutting with any one of the three species is likely operationally feasible, based on our results. It could be used to supplement the low level of natural regeneration that occurs in these forests (Huggard et al. 2005). However, further testing is necessary over a wider set of environmental conditions and over several years. Different results might be obtained, for example, if planting occurred in a dry year, or on coarser textured soils that are more subject to moisture deficits. Small mammal and cattle damage has also been reported following planting IDF sites (Thrower and Associates 1999) and could influence results. Under drier conditions than our study, lodgepole pine may grow more slowly in the shade than Douglas-fir or ponderosa pine over the long term because of its lower water use efficiency, even though it grew fastest at all but lowest light levels in our mesic conditions.

\section{Acknowledgments}

We wish to acknowledge the Kamloops Forest District for arranging the site preparation and supplying the planting stock, and to thank David Meige, Alice Ortner, and Jean Roach, for their assistance at various stages of the project. Don Sachs carried out the statistical analyses. Walt Klenner provided logistical support throughout the project and Andre Arsenault provided similar support in its later stages. Funding for this project was provided by Forest Renewal B.C. and Forest Innovation Investment.

This paper is a contribution of the Opax Mountain Silvicultural Systems Project. The multi-disciplinary project was started in 1992 near Kamloops B.C. to develop a better understanding of the consequences of applying different silvicultural systems in the dry sub-zones of the Interior Douglas-fir biogeoclimatic zone in the south central portion of British Columbia.

\section{References}

Armleder, H.M., R.J. Dawson and R.N. Thomson. 1986. Handbook for timber and mule deer management coordination on winter ranges in the Cariboo Forest Region. B.C. Min. For., Land Manage. Handb. $13.98 \mathrm{p}$

Bealle-Statland, C. 1998. Stand structure and growth estimates for the Opax Mountain Silvicultural systems trial. In A. Vyse, C. Hollstedt and D.J. Huggard (eds.). Managing the dry Douglasfir Forests of the Southern Interior: Workshop Proceedings. pp. 136-148. B.C. Ministry of Forests. Working Paper 14.

Brooks, J.R., L.B. Flanagan, G.T. Varney and J.R. Ehleringer. 1997. Vertical gradients in photosynthetic gas exchange characteristics and refixation of respired $\mathrm{CO}_{2}$ within boreal forest canopies. Tree Phys. 17: $1-12$.

Canham, C.D. 1988. An index for understory light levels in and around canopy gaps. Ecology 65: 1634-1638.

Canham, C.D. 1995. GLI/C - software for calculation of light transmission through forest canopies using color fisheye photography. Institute of Ecosystem Studies, Millbrook, N.Y.

Carter, R.E. and K. Klinka. 1992. Variation in shade tolerance of Douglas-fir, western hemlock, and western red cedar coastal British Columbia. For. Ecol. Manage. 55: 87-105.

Coates, D. and P.J. Burton. 1999. Growth of planted tree seedlings in response to ambient light levels in northwestern interior cedar-hemlock forests of British Columbia. Can J. For. Res. 29: 1374-1382.

Comeau, P.G., F. Gendron and T. Letchford. 1998. A comparison of several methods for estimating light under a paper birch mixedwood stand. Can. J. For. Res. 28: 1843-1850.

Daintith, N., T. Newsome and L. Konowalyk. 1993. Improving Douglas-fir survival and growth by planting under a stand of juvenile lodgepole pine. B.C. Ministry of Forests, Williams Lake, B.C. Extension Note No. 6. pp

Dawson, T.E., S. Mambelli, A.H. Plamboeck, P.H. Templer and K.P. Tu. 2002. Stable isotopes in plant ecology. Ann. Rev. Ecol. Syst. 33: 507-559.

Delong, D.L., S.W. Simard, P.G. Comeau, P.R. Dykstra and S.J. Mitchell. 2005. Survival and growth responses of planted seedlings in root disease infected partial cuts in the Interior Cedar Hemlock zone of southeastern British Columbia. For. Ecol. Manage. 206: 365-379.

Draper, N.R., and H. Smith. 1998. Applied Regression Analysis. Third Edition. John Wiley \& Sons, Inc., New York. 706 p.

Drever, R.C. and K.P. Lertzman. 2001. Light-growth responses of coastal Douglas-fir and western redcedar saplings under different regimes of soil moisture and nutrients. Can. J. For. Res. 31: 2124-2133.

Emmingham, W.H. and R.H. Waring. 1973. Conifer growth under different light environments in the Siskiyou Mountains of southwestern Oregon. Northwest Science 47: 88-99.

Environment Canada. 2005. Canadian Daily Climate Data CDs, available at http://www.climate.weatheroffice.ec.gc.ca/prods_servs/ cdcd_iso_e.html

Ferguson, D.E., A.R. Stage and R.J. Boyd. 1986. Predicting regeneration in the grand fir-cedar-hemlock ecosystem of the northern Rocky Mountains. For. Sci. Monogr.26. 41 p. 
Fleming, R.L., T.A. Black and N. R. Eldridge. 1994. Effects of site preparation on root zone soil water regimes in high elevation forest clearcuts. For. Ecol. Manage. 68: 173-188.

Fleming, R.L., T.A. Black, R.S. Adams and R.J. Stathers. 1998. Silvicultural treatments, microclimatic conditions and seedling response in southern interior clearcuts. Can. J. Soil Sci. 78: 115-126. Goldberg, D.E., T.Rajaniemi, J.Gurevitch and A. Stewart-Oaten, A. 1999. Empirical approaches to quantifying interaction intensity: competition and facilitation along productivity gradients. Ecology 80: $1118-1131$.

Grime, J.P. 2001. Plant strategies, vegetation processes, and ecosystem properties. Second Edition. John Wiley \& Sons, Chichester. 417 p.

Heineman, J., G.D. Hope, S.W. Simard, A. Vyse, D.L. Lloyd and D.J. Miege. 2003. The effects of site preparation and harvesting practices on planted seedling productivity and microenvironment in southern interior dry, grassy IDF forest. Ministry of Forests, Victoria, B.C. Tech Report 009. 22 p.

Hope, G.D., W.R. Mitchell, D.A. Lloyd, W.R. Erickson, W.L. Harper and B.M. Wikeem. 1991. Interior Douglas-fir Zone. In D. Meidinger and J. Pojar (eds.). Ecosystems of British Columbia. pp. 153-166. B.C. Ministry of Forests, Victoria, B.C.

Huggard, D.J., A. Arsenault, D. Lloyd, A. Vyse and W. Klenner. 2005. The Opax Mountain Silviculture Systems Project: preliminary results for managing complex, dry interior Douglas-fir forests. Ministry of Forests Research Program, Extension Note 72. 16 p.

Huggard, D.J. and A. Vyse. 2003. Site preparation alternatives in the wet cold ESSF: Results from Sicamous Creek. British Columbia Ministry of Forests, Forest Science Program, Extension Note 65. 10 p. Klenner, W. and A. Vyse. 1998. The Opax Mountain Silvicultural Systems Project: Evaluating alternative approaches to managing dry Douglas-fir forests. In A. Vyse, C. Hollstedt and D.J. Huggard (eds.). Managing the dry Douglas-fir Forests of the Southern Interior: Workshop Proceedings. pp. 128-135. Ministry of Forests, Victoria, B.C. Working Paper 14.

Klinka, K., Q. Wang, G.J. Kayahara, R. E. Carter and B.A. Blackwell. 1992. Light-growth response relationships in Pacific silver fir (Abies amabilis) and subalpine fir (Abies lasiocarpa). Can. J. Bot. 70: 1919-1930.

Klinka, K., J. Worrall, L. Skoda and P. Varga. 2000. The distribution and synopsis of ecological and silvical characteristics of tree species of British Columbia's forests. Canadian Cartographics Ltd., Vancouver, B.C. 180 p.

Lavender, D.P. 1990. Regenerating British Columbia Forests. University of British Columbia Press, Vancouver, B.C. 372 p.

Lemmon, P.E. 1957. A new instrument for measuring forest overstory density. J. For. 55: 667-668.

Lieffers, V.J., C. Messier, K.J. Stadt, F. Gendron and P.G. Comeau. 1999. Predicting and managing light in the understory of boreal forests. Can. J. For. Res. 29: 796-811.

Livingston, N.J., R.D. Guy, Z.J. Sun and G.J. Ethier. 1999. The effects of nitrogen stress on the stable carbon isotope composition, productivity and water use efficiency of white spruce (Picea glauca [Moench] Voss) seedlings. Plant Cell Environ. 22: 281-289.

Lloyd, D., K. Angove, G. Hope and C. Thompson. 1990. A guide to site identification and interpretation for the Kamloops Region. B.C. Ministry of Forests, Victoria, B.C. Land Management Handbook 23. $399 \mathrm{p}$

Marshall, J.D. and J. Zhang. 1994. Carbon isotope discrimination and water-use efficiency in native plants of the north-central Rockies. Ecology 75: 1887-1895.
Ministry of Forests, 1992. Correlated guidelines for management of dry belt Douglas-fir stands in British Columbia. Ministry of Forests, Victoria, B.C. 59 p.

Mitchell, A.K., B.G. Dunsworth, J.T. Arnott, R. Koppenaal, R.A. Benton, G. Goodmanson, T.A. Bown and J. Sandford. 2004. Growth limitations of planted conifers regenerating under Montane Alternative Silviculture Systems (MASS): Seven-year results. For. Chron. 80: 241-250.

Newsome, T. 1998. Site preparation on dry grassy sites in the Cariboo Region. In A. Vyse, C. Hollstedt and D.J. Huggard (eds.). Managing the dry Douglas-fir Forests of the Southern Interior: Workshop Proceedings. pp. 53-61. Ministry of Forests, Victoria, B.C. Working Paper 14.

Nicholson, A. 1989. Water relations, survival and growth of Douglas-fir seedlings at a pinegrass dominated site in south-central British Columbia. For. Can. and B.C. Min. For., Victoria, B.C. FRDA Memo $121.2 \mathrm{p}$.

Pacala, S.W., C.D. Canham, J.A. Silander Jr. and R.K. Kobe. 1994. Sapling growth as a function of resources in a north temperate forest. Can. J. For. Res. 24: 2172-2183.

Paterson, L. 1997. An evaluation of Gabel Corporation's Model MP917 Time Domain Reflectometry equipment for measuring the moisture content of a forest soil. B.Sc. thesis. Univ. B.C., Faculty of Agriculture, Vancouver.

Simard, S.W., M.D. Jones, D.M. Durall, G.D. Hope, R.J. Stathers, N.S. Sorensen and B.J. Zimonick. 2003. Chemical and mechanical site preparation: effects on Pinus contorta growth, physiology, and microsite quality on grassy, steep forest sites in British Columbia. Can. J. For. Res. 33: 1495-1515.

Simpson, D.G. 2000. Water use of interior Douglas-fir. Can J. For. Res. 30: 534-547.

SPSS. 1997. Systat 7.0 for Windows. Chicago, SPSS Inc.

Stathers, R. J. 1989. Summer frost in young plantations. B.C. Ministry of Forests, Victoria, B.C. FRDA Report 073. 24 p.

Tabachnick, B.G. and L.S. Fidell. 2001. Using multivariate statistics. Fourth Edition. Harper Collins, New York. 966 p.

Thrower and Associates Ltd. 1999. Protocols for managing interior Douglas-fir. J.S. Thrower and Associates Report on Project WCK046. Kamloops, B.C. 62 p.

Virgona, J.M. and D.G. Farquhar. 1996. Genotypic variation in relative growth rate and carbon isotope discrimination in sunflower is related to photosynthetic capacity. Aust. J. Plant Physiol. 23: 227-236 Vyse, A., R.A. Smith and B.G. Bondar. 1991. Management of Interior Douglas-fir stands in British Columbia: past present and future. In D.M. Baumgartner (ed.). Interior Douglas-fir: the species and its management. pp. 177-185. Washington State University, Department of Natural Resource Sciences. Pullman, Washington. Williams, H., C. Messier and D.D. Kneeshaw. 1999. Effects of light availability and sapling size on the growth and crown morphology of understory Douglas-fir and lodgepole pine. Can. J. For. Res. 29: 222-231.

Wolf, D.C., J.O. Legg and T.W.Boutton. 1994. Isotopic methods for the study of soil organic matter dynamics. In R. Weaver (ed.). Methods of Soil Analysis: 2. Microbiological and Biochemical Properties. pp. 865-906. Soil Science Society of America, Madison, Wisconsin, U.S.A. No. 5.

Wright, E.F., K.D. Coates, C.D. Canham and P. Bartemucci. 1998. Species variability in growth response to light across climatic regions in northwestern British Columbia. Can. J. For. Res. 28: 871-886. 